\title{
Petrocodon ionophyllus, a new species of Gesneriaceae from the limestone areas of South China
}

\author{
Li S. ${ }^{1,2}$, Pan B. ${ }^{1}$, Xin Z.B. ${ }^{1,2}$, Fu L.F. ${ }^{1,2}$, Huang Z.J. ${ }^{1,2} \&$ F. Wen ${ }^{1,2 *}$ \\ ${ }^{1}$ Guangxi Key Laboratory of Plant Conservation and Restoration Ecology in Karst Terrain, \\ Guangxi Zhuangzu Autonomous Region, Chinese Academy of Sciences, Guilin - 541 006, China. \\ ${ }^{2}$ Gesneriad Conservation Center of China (GCCC), Guilin Botanical Garden, \\ Chinese Academy of Sciences, Guilin - 541 006, China. \\ *E-mail: wenfang760608@139.com
}

\begin{abstract}
A new species, Petrocodon ionophyllus F.Wen, S.Li \& B.Pan, from the limestone area of Southwestern Guangxi, South China is described here. Based on the population information and threatened situation, the current existence status of this species is assessed as 'Endangered'.
\end{abstract}

Keywords: Endemic, Limestone Flora, New Taxa, Petrocodon integrifolius, Southwestern Guangxi.

\section{Introduction}

Since 2011, our understanding of generic limits in Chinese Gesneriaceae has improved considerably following the integration of additional morphological and molecular data (Möller et al., 2016; Möller, 2019). In particular, a number of monotypic and small genera that were considered endemic to or mainly existing in China have been merged. The new classification in Gesneriaceae is based heavily on molecular-phylogenetic results, with a morphological character or a suite of characters used to support the new taxonomic boundaries. This has also provided a more suitable framework for further research of new Gesneriaceae taxa (Wen et al., 2011; Weber et al., 2011, 2013; Möller et al., 2011, 2014; Möller, 2019; Wen et al., 2019), for example some new genera, Billolivia D.J.Middleton (Middleton et al., 2014), Chayamaritia D.J.Middleton \& Mich.Möller (Middleton et al., 2015a), Litostigma Y.G.Wei,

Received: 04.12.2019; Revised \& Accepted: 20.03.2020

Published Online: 11.05.2020
F.Wen \& Mich.Möller (Wei et al., 2010a), Rachunia D.J.Middleton \& C.Puglisi (Middleton et al., 2018), Tribounia D.J.Middleton (Middleton \& Möller, 2012), and many new species, viz. Oreocharis duyunensis Z.Y.Li, X.G.Xiang \& Z.Y.Guo (Guo et al., 2018), Paraboea dushanensis W.B.Xu \& M.Q.Han, $P$. sinovietnamica W.B.Xu \& J.Guo and $P$. xiangguiensis W.B.Xu \& B.Pan (Xu et al., 2017), Petrocodon tongziensis R.B.Zhang \& F.Wen (Zhang et al., 2019), Primulina anisocymosa F.Wen, Xin Hong \& Z.J.Qiu (Hong et al., 2019), were confirmed and published in recent years.

The authors have undertaken more than 20 expeditions in karst and non-karst landforms of South and Southwest China and collected a number of Gesneriaceae specimens, including many unknown species since 2013. During this fieldwork, the authors made observations and carried out biological investigations particularly on those unknown taxa, and introduced living material to the nursery and the common garden of the Gesneriad Conservation Centre of China (GCCC) for further study and display.

Living plants of a species of Gesneriaceae with a single flower were observed in the field in Jingxi city, Guangxi, in 2010. Because of some corolla characters (e.g., corolla purple and zygomorphic; tube cylindric and not swollen, much longer than limb; limb lobes subequal with acute apex) hinted that it should belong to Petrocodon Hance (in previous Lagarosolen W.T.Wang) (Wang, 1984; Wang et al., 1990, 1998; Weber et al., 2011). The 
plants were tentatively considered as a possible ecotype of Petrocodon integrifolius (D.Fang \& L.Zeng) A.Weber \& Mich.Möller (Fang et al., 1993; Li \& Wang, 2004; Wei et al., 2010b) because of their similarities in habit. After several years of field investigations, the authors collected further flowering specimens of this species. We carefully observed the morphology of those plants that were introduced and cultivated in the nursery and common garden of GCCC over the following years and confirmed that it can be clearly distinguished from Petrocodon integrifolius. Detailed analysis of morphology, types and other authentic specimens of related species of Petrocodon housed in various herbaria (E, GH, HN, IBK, K, KUN, MO, PE, PH, US and VNMN) and relevant literature (Wang et al., 1990, 1998; Li \& Wang, 2005; Wei, 2006, 2007; Wei et al., 2010b; Wen et al., 2012; Chen et al., 2014; Jiang et al., 2011; Hong et al., 2014; Xu et al., 2014; Li \& Wang, 2015; Middleton et al., 2015b; Yu et al., 2015; Guo et al., 2016; Lu et al., 2017b; Cen et al., 2017, Zhang et al., 2018; Li et al., 2019; Su et al., 2019 a \& b; Zhang et al., 2019) revealed it to be a new a taxon, which is described and illustrated here.

Petrocodon ionophyllus F.Wen, S.Li \& B.Pan, sp. nov.

Figs. $1 \& 2$

Petrocodon ionophyllus can easily be distinguished from other species of Petrocodon by its purplish green to purplish brown leaf blades. Additionally, it closely resembles $P$. integrifolius in having ovate or broadly ovate leaf blades and purple corolla with a long tube and narrowly triangular limb lobes, but differs from it in having 3-5 flowers per cyme (vs. 8$10[-12])$, calyx lobes narrowly lanceolate to linear-lanceolate (vs. triangular), position of upper corolla lobes close together to nearly parallel ( $v s$. spreading, positioned at over $80^{\circ}$ angle) and stamens eglandular puberulent ( $v s$. puberulent and glandular puberulent).

Type: CHINA, Guangxi Zhuangzu Autonomous Region, Jingxi City, Sanhe town, growing in crevices of rocks and cliff on limestone hills, in evergreen broad-leaved forests, rare, $780 \mathrm{~m}$, 08.04.2013, flowering, Bo Pan et al. BP P0783 (holo IBK!; iso IBK!, KUN!).
Perennial herbs forming acaulescent rosettes. Rhizomes subterete, $0.5-1.2 \mathrm{~cm}$ long, 0.2-0.4 cm in diam. Leaves 4-8, clustered at apex of rhizome, opposite; petioles terete, $12-15 \times 1.5-2 \mathrm{~mm}$, dark green with a slightly pale purplish shading, densely pubescent; leaf blade purplish green to purplish brown, chartaceous when dried, often almost symmetrical, ovate or broadly ovate, 3.2-6.4 × 2.8$4.8 \mathrm{~cm}$, broadly cuneate at base, obtuse to acute at apex, margins entire, abaxial surface sparsely strigose, adaxial surface pubescent; lateral veins 24 on each side of midrib, slightly prominent abaxially, slightly sunken adaxially. Cymes 1-2, rarely 4, usually 1-branched with 3-5 flowers; peduncles $5-9 \mathrm{~cm}$ long, $1.2-1.5 \mathrm{~mm}$ in diam., densely pubescent to pilose, green with a purplish shading; bracts 2, lanceolate, 6-10 × 1.5-1.8 mm, apex acuminate, margins entire, abaxially white puberulous, adaxially glabrous, usually caducous; pedicels 4.8-7 mm long, densely puberulent, white. Calyx 5-parted to the base; lobes narrowly lanceolate to linear-lanceolate, 6-8 mm long, c. 1 $\mathrm{mm}$ wide, abaxially puberulent, white, adaxially glabrous, brownish. Corolla purple, white puberulent outside, $2.5-3.2 \mathrm{~cm}$ long; tube infundibuliform, $1.6-1.8 \mathrm{~cm}$ long, c. $3 \mathrm{~mm}$ in diam. at middle, glabrous inside; orifice $c .5 \mathrm{~mm}$ in diam.; limb 2-lipped, adaxial lip 2-lobed, lobes c. $5 \mathrm{~mm}$ long, c. $4 \mathrm{~mm}$ in diam. at base, narrowly triangular; abaxial lip 3-lobed, lobes 6-8 mm long, c. $4.2 \mathrm{~mm}$ in diam. at base, narrowly triangular to narrowly lanceolate, apex attenuate-acuminate, three pale purple longitudinal stripes and puberulent-hairs along the abaxial lip lobes. Stamens 2, deflected to one side (left or right) at the throat of corolla but included, adnate at c. $9 \mathrm{~mm}$ above the corolla tube base; filaments $c .10 \mathrm{~mm}$ long, straight, eglandular puberulent; anthers fused by their entire adaxial surfaces, reniform, white, c. $2 \mathrm{~mm}$ long, glabrous. Staminodes 3, lateral ones adnate to corolla tube $c$. $7 \mathrm{~mm}$ above the base, 9-10 $\mathrm{mm}$ long; the central one adnate to corolla tube $c .5 \mathrm{~mm}$ above the base, c. $1.1 \mathrm{~mm}$ long, all glabrous. Ovary 5.5-6 mm long, $0.7-0.9 \mathrm{~mm}$ in diam., densely white puberulent; style $6.5-7 \mathrm{~mm}$ long, deflected to the other side 

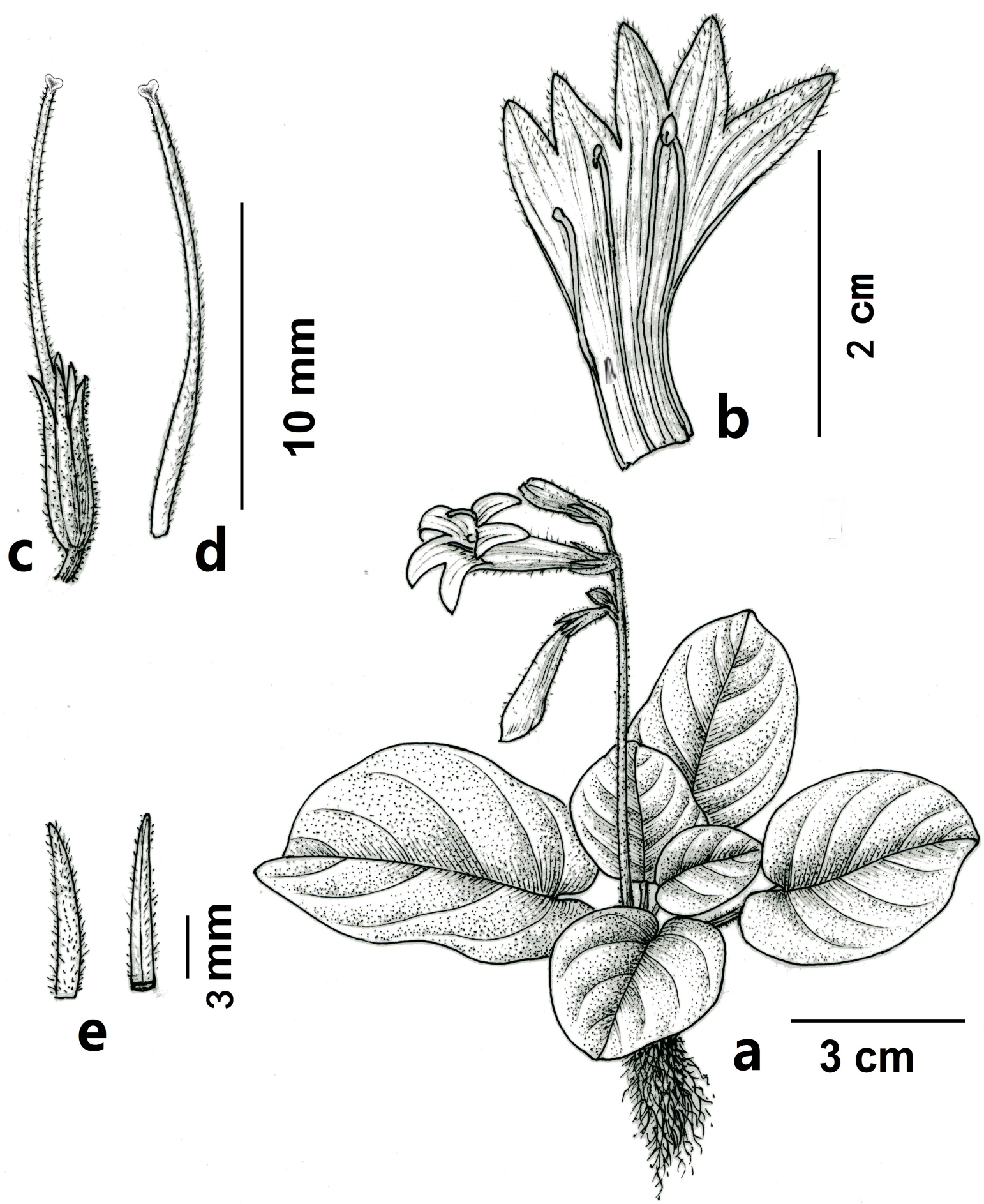

Fig. 1. Petrocodon ionophyllus F.Wen, S.Li \& B.Pan: a. Flowering plant; b. Opened corolla with stamens and staminodes; c. Pistil with calyx; d. Pistil without calyx; e. Bracts (left: abaxial surface; right: adaxial surface) (drawn by Lin Wen-Hong). 

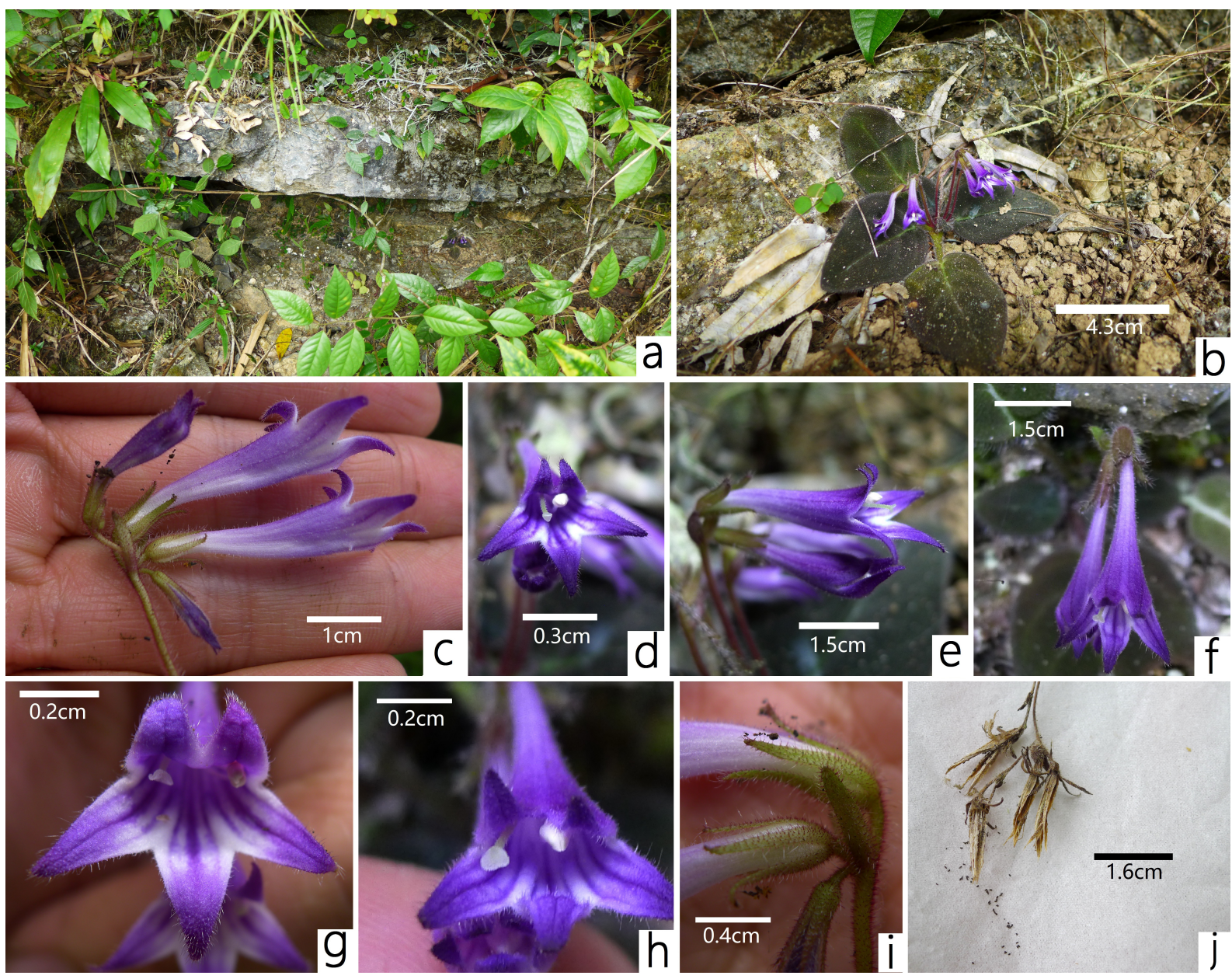

Fig. 2. Petrocodon ionophyllus F.Wen, S.Li \& B.Pan: a. Habitat; b. Flowering plant in natural habitat; c. Lateral view of cyme, inflorescence with open flowers, buds and bracts; $\boldsymbol{d}$. Flower and anthers near corolla; e. Lateral view of corolla; $\mathbf{f}$. Top view of corolla; $\mathbf{g}$. Front view of open flower and enantiostyly, deflection of style (stigma immature) and anthers; h. Stigma mature; i. Indumentum of abaxial surfaces of bracts and calyx lobes; j. Dehisced capsules and seeds (photos by Wen Fang).

away from stamens, densely white glandularpuberulent; disc annular, c. $1 \mathrm{~mm}$ in high, margins entire; stigma bilobed, lobes ovate, $c .0 .6 \mathrm{~mm}$ long. Capsules linear, straight, $1.4-1.7 \mathrm{~cm}$ long, glabrous, 4-valved. Seeds spindle shaped, c. $0.3 \mathrm{~mm}$ long. without hair-like appendages, brown to brownish black.

Flowering \& fruiting: Flowering from April to May and fruiting from June to August.

Habitat: Petrocodon ionophyllus is found growing mostly in crevices and on moist surfaces of limestone rock at elevation range of 740-780 $\mathrm{m}$ in an evergreen broad-leaved forest on a limestone hill. Etymology: The characteristic purplish green to purplish brown leaves of this species are unusual in the genus and distinguishes it from other Petrocodon species. Thus, the specific epithet, "ionophyllus" is chosen, derived from the Greek "ion-" (meaning violet-coloured) and "-phyllus" (leaves), referring to its purple-hued leaves.

Distribution: Petrocodon ionophyllus is only found in Jingxi city, China. The type locality is close to the border between China and Vietnam, hence the distribution of this species might extend into Vietnam.

Conservation status: Currently, only one location with three sub-populations of this new species are known in the wild, with a total of 200 mature individuals on three limestone mountains in Sanhe Town. The mountains do not belong to any of the protected areas or natural reserves, so this population is very vulnerable to local timber 
Table 1. Morphological comparison of Petrocodon ionophyllus (see Fig. 4) and P. integrifolius

\begin{tabular}{|l|l|l|}
\hline Characters & P. ionophyllus F.Wen, S.Li \& B.Pan & $\begin{array}{l}\text { P. integrifolius (D.Fang \& L.Zeng) } \\
\text { A.Weber \& Mich.Möller }\end{array}$ \\
\hline Leaf blade colour & Purplish green to purplish brown & Pale green to green \\
\hline Leaf blade shape & Ovate or broadly ovate & Ovate to orbicular \\
\hline Leaf blade base & Broadly cuneate at base & Obviously cordate, sometimes cuneate \\
\hline Leaf blade indumentum & $\begin{array}{l}\text { Sparsely strigose on adaxial surface, } \\
\text { pubescent on abaxial surface }\end{array}$ & Appressed pubescent on both surfaces \\
\hline Leaf blade apex & Acute to obtuse, no rounded & Obtuse to rounded \\
\hline Number of flowers per cyme & $3-5$ & $8-10$ (or more) \\
\hline Bracts shape & Lanceolate & Oblong to lanceolate \\
\hline Calyx lobe shape & Narrowly lanceolate to linear-lanceolate & Triangular \\
\hline Stamens & Eglandular puberulent & Puberulent and glandular puberulent \\
\hline Ovary & Densely white puberulent & Spreading glandular puberulent \\
\hline
\end{tabular}

harvesting, road construction and other detrimental factors. Because only one location (with $<250$ mature plants) has been found so far, we recommend that this species should be provisionally treated as Endangered (EN) under category D for very small or restricted population (IUCN, 2019).
However, this status could be reassessed in the future fieldwork.

Notes: The expanded genus Petrocodon and the many new published species resulted in a genus with various flower shapes, stamen numbers and

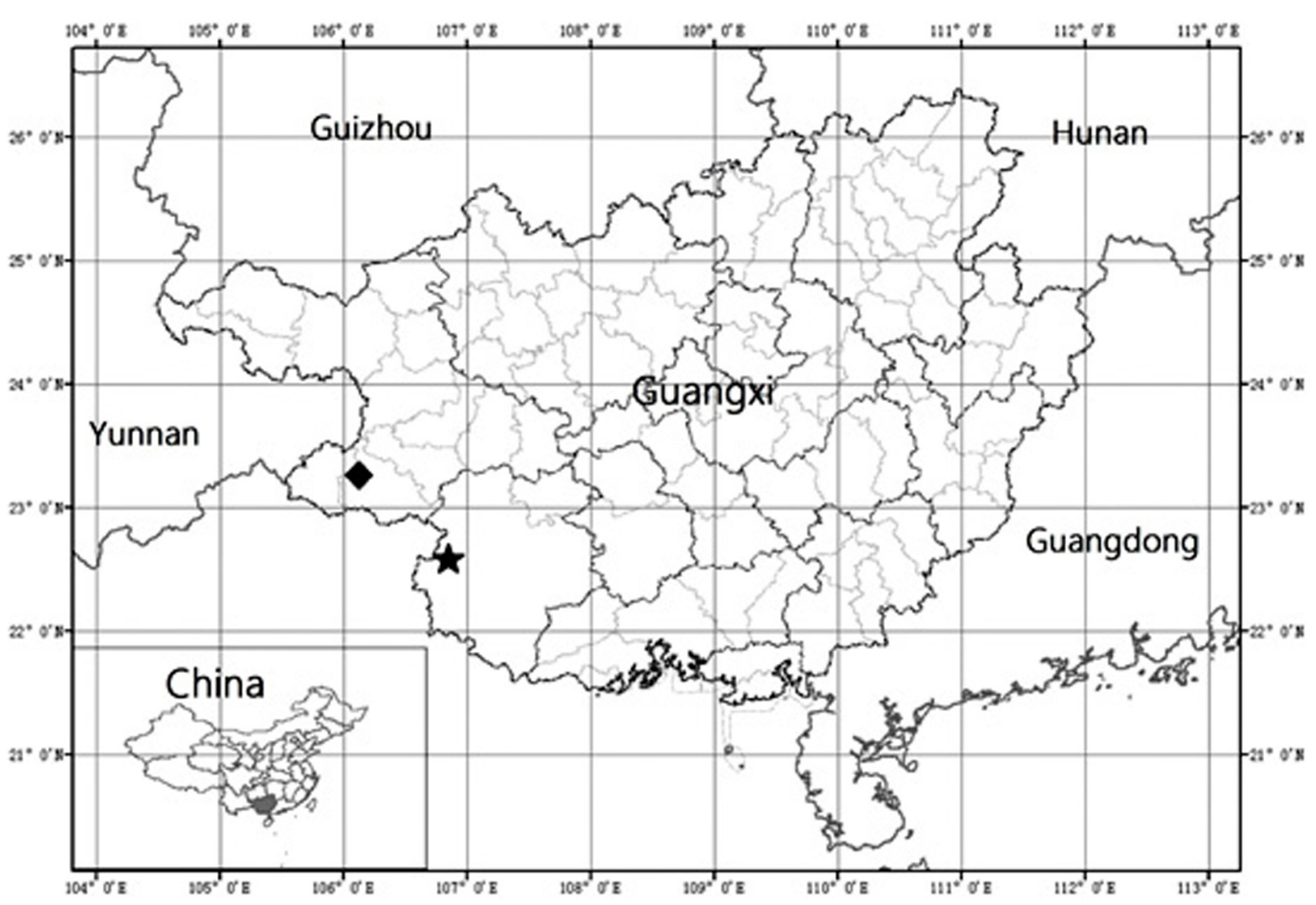

Fig. 3. Distribution of Petrocodon ionophyllus F.Wen, S.Li \& B.Pan ( $)$ and its morphologically similar species, P. integrifolius (D.Fang \& L.Zeng) A.Weber \& Mich.Möller (*). 

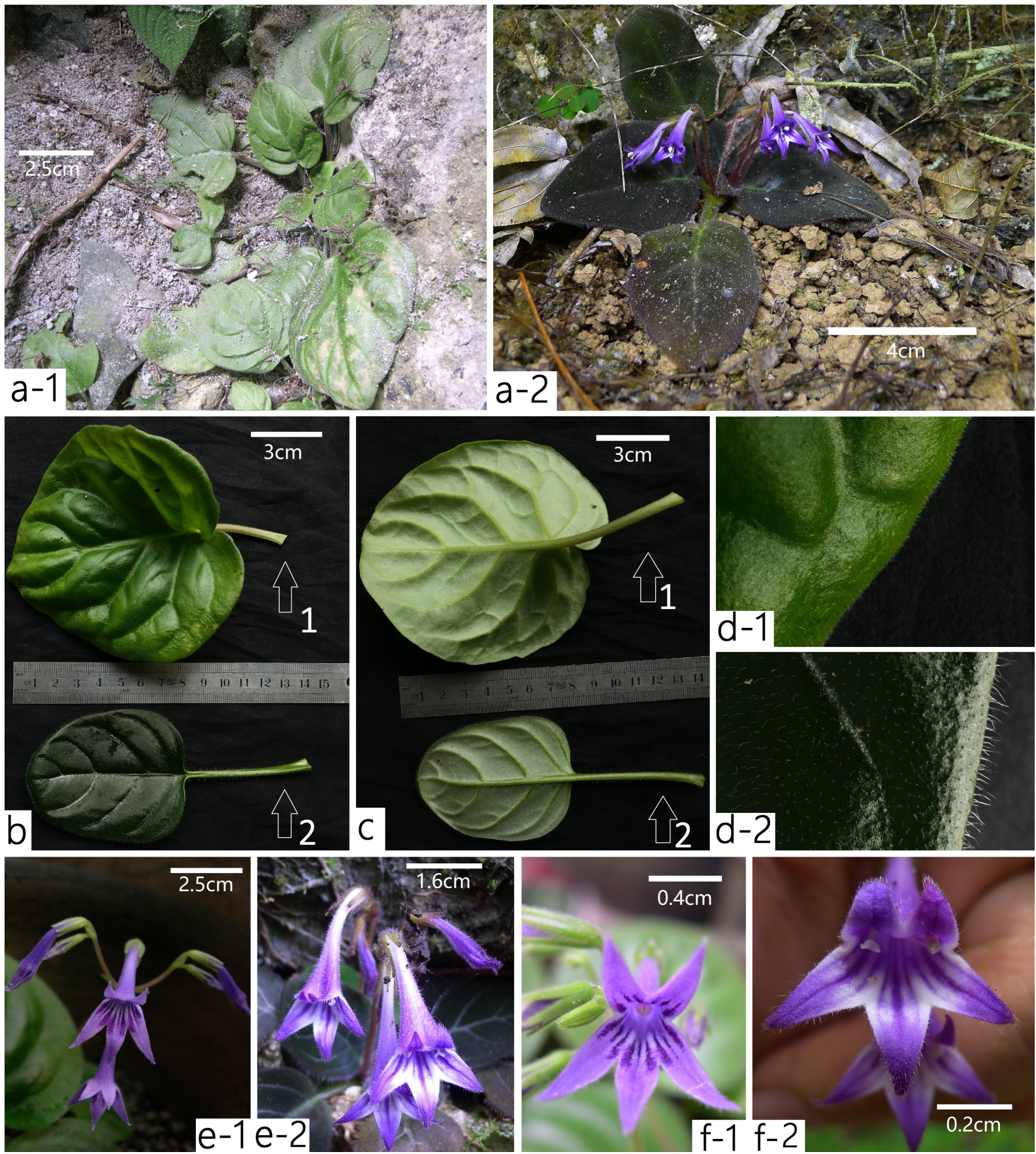

Fig. 4. Morphology comparison between Petrocodon ionophyllus F.Wen, S.Li \& B.Pan and P. integrifolius (D.Fang \& L.Zeng) A.Weber \& Mich.Möller: (a. Habitat; b., c., d., e. After common garden experiment). 1. Petrocodon integrifolius; 2. P. ionophyllus: a. Habitat; b. Adaxial view of leaves; c. Abaxial view of leaves; d. Indumentum of leaf margins; e. Inflorescences; f. Frontal view of corollas (photos by Wen Fang).

colours (Weber et al., 2011; Lu et al., 2017a). The genus currently harbours almost 40 species and has its distribution centre in the mountainous area of southwestern and southern China (Wen et al., 2019, 2014 onw.). Only four species have been found distributed outside China, namely Petrocodon coccineus (C.Y.Wu ex H.W.Li) Yin.Z.Wang and P. hispidus (W.T.Wang) A.Weber \& Mich.Möller (both distributed in China and Vietnam), P. bonii (Pellegr.) Mich.Möller \& A.Weber (distributed in Laos, Thailand and Vietnam, not in China) and $P$. flavus D.J.Middleton \& Sangvir (endemic to 
Thailand) (Burtt, 2001; Phuong, 2006; Weber et al., 2011; Middleton et al., 2015b).

The morphological variation between Petrocodon species is rather diverse, yet we identified this species mistakenly as $P$. integrifolius when this plant was discovered because of their morphological similarities. The new species, P. ionophyllus, occurs in Jingxi City of Guangxi and grows on the surfaces and in crevices of limestone rocks under forests up to an altitude of about 750 meters. However, $P$. integrifolius is distributed in Longzhou County of Guangxi, and only grows in deep caves at altitudes between 200 to 530 meters (Fig. 3). In their native habitat, the new species grows significantly smaller than P. integrifolius, the texture of the leaves is hard, chartaceous to nearly leathery, and the hairs on the leaves are rough. The leaves of P. integrifolius are thin like paper, and pubescent. Living plants from the type localities of of both species, Longzhou and Jingxi, were introduced to the greenhouses of GCCC. The differences observed in the filed between these species were found to be consistent even after 4 years of cultivation. In P. ionophyllus, exhibit reciprocal enantiostyly where the style is deflected to one side and the stamen to the other, which is perhaps to reduce autogamy (Jesson \& Barrett, 2002, 2003) (Table 1, Fig. 4).

This is similar to the mirror-image flowers described in Paraboea rufescens (Franch.) Burtt (Gao et al., 2006). Further, the florescence of the two species are different; the flowering period of Petrocodon ionophyllus is from April to May, whereas P. integrifolius begins to bloom from June onwards.

\section{Acknowledgements}

We are grateful to Mr.Wen-Hong Lin for botanical drawing; Ms. Jia Dong, who graduated from University of Edinburgh, UK, for checking the grammar; two anonymous reviewers and Dr. Michael Möller for their helpful suggestions. This study was financially supported by the National Natural Science Foundation (31860047), the Foundation of Guangxi key Laboratory of Plant Conservation and Restoration Ecology in Karst
Terrain (19-050-6), the Guangxi Natural Science Foundation (2017GXNSFAA198006), the STS Program of the Chinese Academy of Sciences (KFJ3 W-No1) and Guilin Science and Technology Foundation (20180107-6).

\section{Literature Cited}

BURTT B.L. 2001. Flora of Thailand: annotated checklist of Gesneriaceae. Thai Forest Bulletin (Botany) 29: 81109.

CEN H.F., FU L.F. \& F. WEN 2017. Petrocodon urceolatus sp. nov. (Gesneriaceae) from Zhangjiajie city, Northwestern Hunan Province, China. Nordic Journal of Botany 35(3): 334-338. https://doi.org/10.1111/ njb.01333

CHEN W.H., MÖLLER M., SHUI Y.M., WANG H., YANG J.B. \& G.Y. LI 2014. Three new species of Petrocodon (Gesneriaceae), endemic to the limestone areas of southwest China, and preliminary insights into the diversification patterns of the genus. Systematic Botany 39(1): 316-330. https://doi.org/10.1600/ 036364414 X678189

FANG D., QIN D.H. \& L. ZENG 1993. New plants of Gesneriaceae from Guangxi of China. Acta Phytotaxonomica Sinica 31(5): 463-471.

GAO J.Y., REN P.Y., YANG Z.H. \& Q.J. LI 2006. The pollination ecology of Paraboea rufescens (Gesneriaceae): a buzz-pollinated tropical herb with mirror-image flowers. Annals of Botany 97(3): 371-376. https://doi.org/ 10.1093/aob/mcj044

GUO J., MENG T., PANG H.B. \& Q. ZHANG 2016. Petrocodon retroflexus sp. nov. (Gesneriaceae) from a karst cave in Guizhou, China. Nordic Journal of Botany 34(2):159-164. https://doi.org/10.1111/njb.00941

GUO Z.Y., LI Z.Y. \& X.G. XIANG 2018. Oreocharis duyunensis (Gesneriaceae), a new species from Guizhou, China. Nordic Journal of Botany 36(9): e01514. https:// doi.org/10.1111/njb.01514

HONG X., ZHOU S.B. \& F. WEN 2014. Petrocodon villosus (Gesneriaceae), a new species from Guangxi, China. Blumea 59(1): 33-36. https://doi.org/10.3767/ 000651914 X682378

HONG X., KEENE J., QIU Z.J. \& F. WEN 2019. Primulina anisocymosa (Gesneriaceae), a new species with a unique inflorescence structure from Guangdong, China. Peer 7: e6157. https://doi.org/10.7717/peerj.6157

IUCN Standards and Petitions Subcommittee 2019. Guidelines for using the IUCN Red List Categories and Criteria. Version 14. Prepared by the Standards and Petitions Subcommittee of the IUCN Species Survival 
Commission. Available at: http://cmsdocs. s3.amazonaws .com/RedListGuidelines.pdf (Accessed on 01.08.2019).

JESSON L.K. \& S.C.H. BARRETT 2002. Enantiostyly: solving the puzzle of mirror-image flowers. Nature 417(6890): 707. https://doi.org/10.1038/417707a

JESSON L.K. \& S.C.H. BARRETT 2003. The comparative biology of mirrorimage flowers. International Journal of Plant Sciences 164 (S55): S237-S249. https://doi.org/ 10.1086/378537

JIANG Y.S., ZHANG Y., WANG Y. \& F. WEN 2011. Petrocodon multiflorus sp. nov. (Gesneriaceae) from Guangxi, China. Nordic Journal of Botany 29(1): 57-60. https://doi.org/10.1111/j.1756-1051.2010.00874.x

LI C.R., LIU F.P., GADAGKAR S.R. \& Y. LUO 2019. Petrocodon longitubus (Gesneriaceae), a new species from Guizhou, China. Phytotaxa 408(4): 267-275. https:// doi.org/10.1600/036364414X678189

LI H.Q. \& Y.Q. WANG 2015. Petrocodon confertiflorus (Gesneriaceae), a new pecies from Guangdong, China. Annales Botanici Fennici 52: 27-32. https://doi.org/ 10.5735/085.052.0204

LI Z.Y. \& Y.Z. WANG 2005. Plants of Gesneriaceae in China. Henan Science and Technology Press, Zhengzhou, China. p. 721.

LU Y.B., HUANG Y.S., XU W.B., HUANG J., LIU Y., XIANG C.L. \& Q. ZHANG 2017a. Floral evolutionary trend of Petrocodon (Gesneriaceae) and its significance in classification. Guihaia 10(37): 1227-1239. https:// doi.org/10.11931/guihaia.gxzw201611029

LU Y.B., PAN B., HUANG J. \& Q. ZHANG 2017b. Petrocodon pulchriflorus sp. nov. (Gesneriaceae) from Guangxi, China. Phytotaxa 291 (1): 81-88. https:// doi.org/10.1600/036364414X678189

MIDDLETON D.J., ATKINS H., TRUONG L.H., NISHII K. \& M. MÖLLER 2014. Billolivia, a new genus of Gesneriaceae from Vietnam with five new species. Phytotaxa 161(4): 241-269. http://dx.doi.org/10.11646/ phytotaxa.161.4.1

MIDDLETON D.J., KHEW G.S., POOPATH M., MÖLLER M. \& C. PUGLISI 2018. Rachunia cymbiformis, a new genus and species of Gesneriaceae from Thailand. Nordic Journal of Botany 36(1): e01992. https://doi.org/10.1111/njb.01992

MIDDLETON D.J. \& M. MÖLLER 2012. Tribounia, a new genus of Gesneriaceae from Thailand. Taxon 61(6): 1286-1295. https://doi.org/10.1002/tax.616009

MIDDLETON D.J., NISHII K., PUGLISI C., FORREST L.L. \& M. MÖLLER 2015a. Chayamaritia (Gesneriaceae: Didymocarpoideae), a new genus from Southeast Asia. Plant Systematics and Evolution 301(7): 1947-1966. https:/ /doi.org/10.1007/s00606-015-1213-2
MIDDLETON D.J., SANGVIROTJANAPAT S. \& W. LA-ONGSRI 2015b. A new species of Petrocodon (Gesneriaceae) from Thailand. Thai Forest Bulletin (Botany) 43: 15-17.

MÖLLER M. 2019. Species discovery in time: an example from Gesneriaceae in China. Guangxi Sciences 26(1): 116. https://doi.org/10.13656/j.cnki.gxkx.20190307.002

MÖLLER M., MIDDLETON D.J., NISHII K. \& Y.G. WEI 2011. A new delineation for Oreocharis incorporating an additional ten genera of Chinese Gesneriaceae. Phytotaxa 23(1): 1-36. http://dx.doi.org/10.11646/ phytotaxa.23.1.1

MÖLLER M., NISHII K., ATKINS H.J., KANG M, WEI Y.G., WEN F., HONG X. \& D.J. MIDDLETON 2014. An expansion of the genus Deinostigma (Gesneriaceae). Gardens' Bulletin Singapore 68(1): 145-172.

MÖLLER M., WEI Y.G., WEN F., CLARK J.L. \& A. WEBER 2016. You win some you lose some: updated generic delineations and classification of Gesneriaceaeimplications for the family in China. Guihaia 36(1): 4460. https://doi.org/10.11931/guihaia.gxzw201512015

PHUONG V.X. 2006. One new genus of the family Gesneriaceae for the flora of Vietnam. Tap Chi Sinh Hoc 28(4): 37-39.

SU L.Y., PAN B., HONG X., ZHAO Z.G., FU L.F., WEN F. \& S. MACIEJEWSKI 2019a. Petrocodon jiangxiensis (Gesneriaceae), a new species from Jiangxi, China. Annales Botanici Fennici 56 (4-6): 277-284. https:// doi.org/10.5735/085.056.0413

SU L.Y., PENG T., ZHAO Z.G., PAN B. \& F. WEN 2019b. Petrocodon chongqingensis, a new species of Gesneriaceae from Chongqing City, China. Guihaia 39(8): 997-1006. https://doi.org/10.11931/guihaia. gxzw201903010

WANG W.T. 1984. Notulae de Gesneriaceis Sinensibus (VI). Acta Botanica Yunnanica 6(1): 11-14.

WANG W.T., PAN K.Y. \& Z.Y. LI 1990. Gesneriaceae. In: WANG W.T. (ed.), Flora Reipublicae Sinicae. Volume 69. Science Press. Beijing, China. pp. 125-581.

WANG W.T., PAN K.Y., Li Z.Y., A.L. WEITZMAN \& L.E. SKOG 1998. Gesneriaceae. In: WU Z.Y. \& P.H. RAVEN (eds.), Flora of China, Volume 18. Science Press, Beijing and Missouri Botanical Garden Press, St. Louis. pp. 244-401.

WEBER A., WEI Y.G., PUGLISI C., WEN F., MAYER V. \& M. MÖLLER 2011. A new definition of the genus Petrocodon (Gesneriaceae). Phytotaxa 23(1): 49-67.http:/ /dx.doi.org/10.11646/phytotaxa.23.1.3

WEBER A., CLARK J.L. \& M. MÖLLER 2013. A new formal classification of Gesneriaceae. Selbyana 31(2): 6894. https://doi.org/10.2307/24894283 
WEI Y.G. 2006. A new species of Lagarosolen W.T.Wang (Gesneriaceae) from Guangxi province, China. Kew Bulletin 61: 273-275. https://doi.org/10.2307/20443274

WEI Y.G. 2007. Petrocodon ferrugineus (Gesneriaceae), a new species from Guangxi, China. Novon 17(1): 135-137. https://doi.org/10.3417/1055-3177(2007)17

WEI Y.G., WEN F., CHEN W.H., SHUI Y.M. \& M. MÖLLER 2010a. Litostigma, a new genus from China: a morphological link between basal and derived didymocarpoid Gesneriaceae. Edinburgh Journal of Botany 67(1): 161-184. https://doi.org/10.1017/ S0960428609990291

WEI Y.G., WEN F., MÖLLER M., MONRO A., ZHAN Q., GAO Q., MOU H.F., ZHONG S.H. \& C. CUI 2010b. Gesneriaceae of South China. Guangxi Science and Technology Publishing House Press, Nanning. p. 777.

WEN F., LIANG G.Y. \& Y.G. WEI 2012. Petrocodon lancifolius (Gesneriaceae), a new species endemic to a central subtropical zone of Guizhou Province, China. Phytotaxa 49(1): 45-49. http://dx.doi.org/10.11646/ phytotaxa.49.1.7

WEN F., WEI Y.G., MÖLLER M. \& F.L. FU 2011. The new classification system of Chinese Gesneriaceae. The $10^{\text {th }}$ Chinese Young Scientists Conference on Systematic and Evolutionary Botany of 2011. Botanical Society of Yunnan China Press. Kunming, China. pp. 117-118.

WEN F., LI S., XIN Z.B., FU L.F., HONG X., CAI L., QIN J.Q., PAN B. \& F.Z. PAN 2019. The updated plant list of Gesneriaceae in China under the new Chinese naming rules. Guangxi Sciences 26(1): 37-63. https:// doi.org/10.13656/j.cnki.gxkx.20190225.002
WEN F., WEI Y.G., FU L.F., XIN Z.B., LI S., HUANG Z.J. \& D.C. MENG 2014 onw. The Checklist of Gesneriaceae in China. Available at: http://gccc.gxib.cn/ about-46.aspx (Accessed on 24.02.2020).

XU W.B., MENG T., ZHANG Q., WU W.H., LIU Y. \& K.F. CHUNG 2014. Petrocodon (Gesneriaceae) in the limestone karsts of Guangxi, China: three new species and a new combination based on morphological and molecular evidence. Systematic Botany 39(3): 965-974. https://doi.org/10.1600/036364414X681437

XU W.B., GUOJ., PANB.,HAN M.Q., LIU Y. \& K.F. CHUNG 2017. Three new species of Paraboea (Gesneriaceae) from limestone karsts of China based on morphological and molecular evidence. Botanical Studies 58: 1-14. https://doi.org/10.1186/s40529-017-0207-5

YU X.L., LI M., ZHOU J.J. \& P.W. LI 2015. Petrocodon hunanensis (Gesneriaceae), a new species identified by both morphological and molecular evidence from limestone area in Hunan, China. Phytotaxa 195(1): 6572. http://dx.doi.org/10.11646/phytotaxa.195.1.4

ZHANG R.L., FU L.F., LI S., WEI Y.G., MACIEJEWSKI S., LOFURNO M. \& F. WEN 2018. Petrocodon asterocal $y x$, a new species of Gesneriaceae from Guangxi, China. Phytotaxa 343(3): 259-268. http://dx.doi.org/ 10.11646/phytotaxa.343.3.6

ZHANG R.B., DENG T., FU L.F., LI S., HE L., DOU Q.L. \& F. WEN 2019. Petrocodon tongziensis (Gesneriaceae), a new species from limestone areas in Guizhou, China based on morphological and molecular evidence. Nordic Journal of Botany 37(2): e01774. https:// doi.org/10.1111/njb.01774 